\title{
Implementasi Knowledge Management System dan Knowledge Sharing Berbasis ChatBot- Penyakit Parvo pada Anjing
}

\author{
I Ketut Widhi Adnyana ${ }^{*}$, Jenny Octavia ${ }^{2}$, Ni Kadek Ariasih ${ }^{3}$ \\ ${ }^{1}$ Sistem Informasi, Institut Teknologi dan Bisnis STIKOM Bali \\ 2 Perhimpunan Dokter Hewan Indonesia (PDHI) \\ ${ }^{3}$ Teknik Informatika, STMIK STIKOM Indonesia \\ $1,2,3$ Bali, INDONESIA \\ 1* widhi_adnyana@stikom-bali.ac.id, ${ }^{2}$ jenny_octavia78@gmail.com, ${ }^{3}$ kadek_ariasih@stiki-indonesia.ac.id
}

\begin{abstract}
Canine Parvovirus is the leading cause of death for dogs, especially in puppies under six months of age. This disease is caused by the Parvovirus. Parvovirus comes from the Latin Parvus which means small. Symptoms of disease caused by CPV are characterized by vomiting and bloody diarrhea with a characteristic odor. Therefore, Parvo disease is often called Gastroenteritis in dogs. Puppies under the age of three months infected with this virus only survive 1-2 days before dying. Knowledge Management is an activity in managing Knowledge as an asset, wherein various strategies there is the distribution of the right Knowledge to the right people and quickly so that they can interact with each other, share knowledge and apply it in their daily work. with the help of a ChatBot which can later help owners or veterinarians to find and provide information about diseases in animals, especially dogs, effectively and efficiently. by using the webhook method to communicate with users via social media Telegram. Webhook is a method that is installed on hosting, by using a webhook the ChatBot application can communicate in real-time.
\end{abstract}

Keywords: ChatBot; Parvo Virus; Artificial Intelligence; Vetenarian.

Abstrak - Canine Parvovirus yakni virus sebab kematian terbanyak dalam bangsa anjing, paling utama pada anak anjing yang berusia dibawah 6 bulan. Penyakit tersebut ditimbulkan Virus Parvo. Virus Parvo bermula bahasa latin parvus memiliki arti kecil. Gejala penyakit ditimbulkan dari CPV dikenali beserta muntah serta menceret keluar darah beserta aroma khusus. Maka sebabnya, penyakit Parvo kerap dikatakan penyakit muntaber anjing. Anak anjing usia dibawah 3 bulan yang terpapar virus tersebut bertahan 1-2 hari sebelum enggan bernyawa. Knowledge Management yakni kativitas pada mengelola ilmu sebagai aset, yang mana pada bermacam strateginya terdapat proses menyalurkan pengetahuan yang tepat pada seorang yang tepat serta pada kesempatan yang cepat, akhirnya ia dapat saling interaksi, bermacam pengetahuan serta mengaplikasikanya pada pekerjaan sehari-hari. beserta pertolongan chatBot yang esoknya bisa menolong pemilik maupun dokter hewan untuk mendapat serta memberi informasi mengenai penyakit dalam hewan terkhusus anjing dengan baik serta efisien. Beserta memakai cara webhook guna melaksanakan komunikasi beserta user lewat social media Telegram. webhook yakni cara yang dipasang dihosting dengan memakai webhook maka aplikasi chatBot bisa berkomunikasi dengan real-time.

Kata Kunci: ChatBot; Virus Parvo; Kecerdasan Buatan; Kedokteran Hewan.

\section{Pendahuluan}

Anjing yakni seekor binatang kesayangan bisa dibuat sahabat, menjaga rumah, berburu, hiburan sirkus, lambang keadaan ataupun komoditi komersial dapat bisa dijual beli lewat bermacam perlomban serta pertunjuakan anjing. Harga jual sekor anjing bisa meninggi pesat jika lolos memenangi sebuah perlombaan. Maka sebabnya, kesehatan anjing butuh dipelihara serta memperoleh prioritas untuk pemilik, didalamnya yakni rancangan proses mencegah menular contohnya vaksinasi pada penyakit rabies, distemper, parainfluenza tipe dua, bordotella pertussis. serta canine Parvovirus. Kesadaran akan bahaya dari penyakit Parvo tersebut terlihat sejak pemilik yang mendahulukan anjingnya guna divaksin paling utama sebelum ikut serta kejuaraan ataupun pertunjukan.
Canine Parvovirus yakni virus menimbulkan kematian teratas dalam golongan anjing, paling utama pada anak anjing yang berusia dibawah 6 bulan. Penyakit tersebut ditimbulkan virus Parvo. Virus Parvo berawal bahasa latin parvus memiki arti kurang besar. Gejala penyakit ditimbulkan oleh virus Parvo ialah terdapatnya beserta muntah serta mencret atau diare berdarah beserta bau yang khas [1], [2]. Maka sebabnya, penyakit Parvo kerap dikatakan penyakit muntaber dalam anjing. Generasi anjing usia dibawah 3 bulan yang terpapar virus tersebut bertahan saja 1-2 hari sebelum mati. Pencegahan penyakit tersebut hanya bisa dilaksanakan beserta memberikan vaksin, meski ketidakberhasilan vaksin terdapat pada banyaknya yang sedikit. Selama masih banyaknya para pemilik anjing yang belum mengetahui cara pemberian pertolongan pertama untuk anjing yang terinfeksi virus 
Parvo [3]. Knowledge Management yakni aktivitas pada proses mengelola ilmu untuk aset, yangmana pada bermacam strateginya terdapat proses menyalurkan ilmu yang sesuai pada seorang yang sesuai serta pada kesempatan yang cepat, akhirnya ia dapat saling interaksi, bermacam pengetahuan serta mengaplikasikanya pada aktivitas sehari-hari [4], [5].

Umumnya, chatBot yakni rancangan komputer yang bisa melaksanakan tugas otomatis, serta bisa memiliki fungsi diplatform pengiriman pesan. ChatBots menirukan percakapan manusia beserta memakai Artificial Intelligence [6]. ChatBot yakni agen percakapan otomatis yang proses interaksi beserta pemakai memakai bahasa alami manusia bisa emnolong kapan pun serta dimana pun. sekarang, dengan proses berkembangnya intelegensi buatan, chatBot dipakai dibanyak bidang, contoh sistem penjawab telepon otomatis, suport pendidikan, berbisnis, e-commerce, asisten virtual utama, tujuanya menghiburkan, menolong seorang melaksanakan perintah dari memberikan jawaban soal, memberi arahan arah mengemudikan, menyalahkan termostat dirumah pintar, serta melagukab musik kesukaan [7], [8].

Tulisan tersebut hendak memaparkan terapi CPV dengan memakai gagasan baru memanfaatkan teknologi kecerdasan buatan berupa chatBot yang nantinya dapat membantu pemilik ataupun dokter hewan untuk mencari serta memberikan informasi perihal penyakit pada hewan khususnya anjing secara efektif serta efisien.

\section{Metodologi}

A. Pengumpulan Data
Proses mengumpulkan data dilaksanakan memakai dua teknik yaitu studi pustaka dan wawancara. Proses mengumpulkan data dilaksanakan bertujuan bisa diolah sebelumnya cara proses membuat sistem. Pertama, proses mengumpulkan data dilaksanakan beserta menemukan bermacam literasi contohnya buku, jurnal, proses menelusuri alat jaringan maupun surat-surat berkesinambungan pada ruang lingkup kepenelitian. Kedua, proses mengumpulkan data dilaksanakan beserta metode tanya jawab ataupun melakukan konsultasi langsung beserta drh. Jenny Octavia seorang dokter hewan yang juga yakni anggota dari Perhimpunan Dokter Hewan Indonesia (PDHI). Keadaan tersebut dilaksanakan memiliki tujuan guna memperoleh keterangan semestinya, kemudian data-data sudah terkumpul ditata dijadikan pengetahuan dasar dari chatBot hendak dipakai pada Knowledge sharing.

\section{B. Pra-Proses}

Ketika akan melaksanakan cara rangkaian membuat sistem keterangan telah didapati diolah berubah serangkai tabel AIML. Artificial Intellegence Markup Language yang didalamnya rangkaian pola serta respon yang dapat digunakan chatBot guna menelusuri jawaban dari tiap kalimat yang diberikan [9], [10], [11].

\section{Metode}

Aplikasi chatBot ini menggunakan metode webhook untuk melakukan komunikasi dengan user melalui sosial media Telegram. Webhook yakni metode yang dipasang di hosting dengan menggunakan webhook maka aplikasi chatBot dapat berkomunikasi secara real-time, Gambar 1.

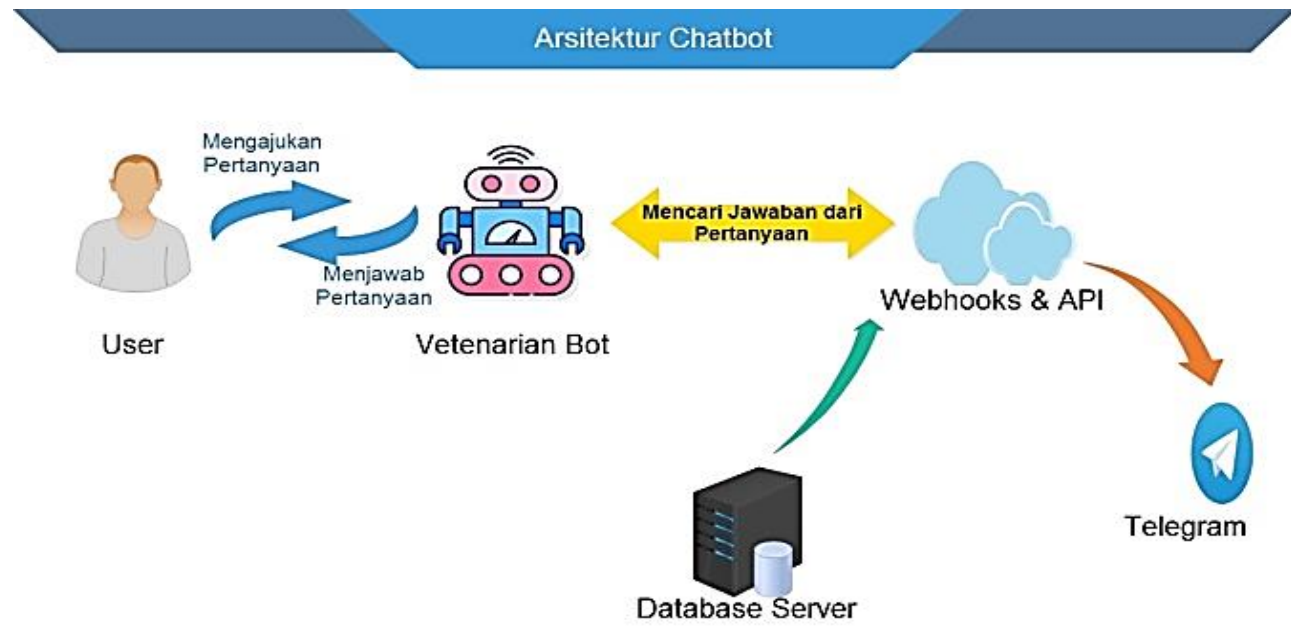

Gambar 1. Arsitektur ChatBot dengan Webhook

\section{Hasil dan Pembahasan}

Langkah awal yakni melaksanakan cara registrasi Bot baru yang hendak ditolong beserta terdapatnya account BotFather. Sesudah seluruh cara registrasi Bot berhasil dilaksanakan, BotFather hendak memberikan informasi berwujud API Token dari Bot yang sudah dibuat. API Token yakni informasi yang dipakai untuk identitas dari sebuah Bot dalam saat melaksanakan request pada berkomunikasi lewat API dalam Telegram server. Cara registrasi yang dilaksanakan bisa disaksikan contohnya Gambar 2.

Setelah berhasil melakukan registrasi Bot Telegram melalui Bot father maka langkah selanjutnya yakni memberikan atau menginputkan Knowledge kepada Bot 


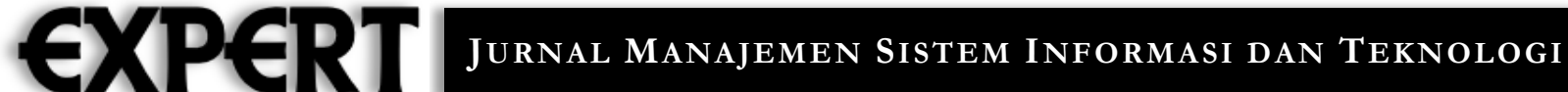

berupa pertanyaan serta jawaban pada aplikasi web dicantumkan pada Gambar 3.

Pada Gambar 3 dapat dijelaskan bagaimana Bot akan merespon pertanyaan dari user. sebagai contoh ketika user memberi input atau mengetikan "/start" maka otomatis Bot akan merespon dengan kalimat: "Hai.. ini yakni Vetenarian Artificial Intellegent Assistent. Atau boleh kamu panggil namaku "Vera". Nama kamu siapa? Kenalan dulu dong, pakai format "namaku ..." tanpa tanda "ya." untuk lebih lanjutnya dilampirkan dalam Tabel 1.

Langkah selanjutnya yakni melakukan integrasi dengan platform Telegram, metode yang digunakan yakni dengan menggunakan token Application Programming Interface (API) dari Bot serta webhook. Token Bot didapatkan pada saat melakukan registrasi melalui BotFather seperti pada Gambar 1, sedangkan untuk webhook ini membutuhkan layanan hosting serta domain yang sudah mendukung protocol https, Gambar 4.

Tahap berikutnya adalah tahap dimana dilakukan pengujian sistem dengan tujuan untuk menentukan apakah Bot dapat membagikan pengetahuan yang dimiliki kepada pengguna. Tabel 2 adalah hasil pengujian menggunakan metode Black Box Testing.

Berikutnya yaitu melakukan pengujian komunikasi melalui Telegram dengan masih sama menggunakan metode Black Box Testing. Tabel 3 adalah hasil uji yang sudah dilakukan.

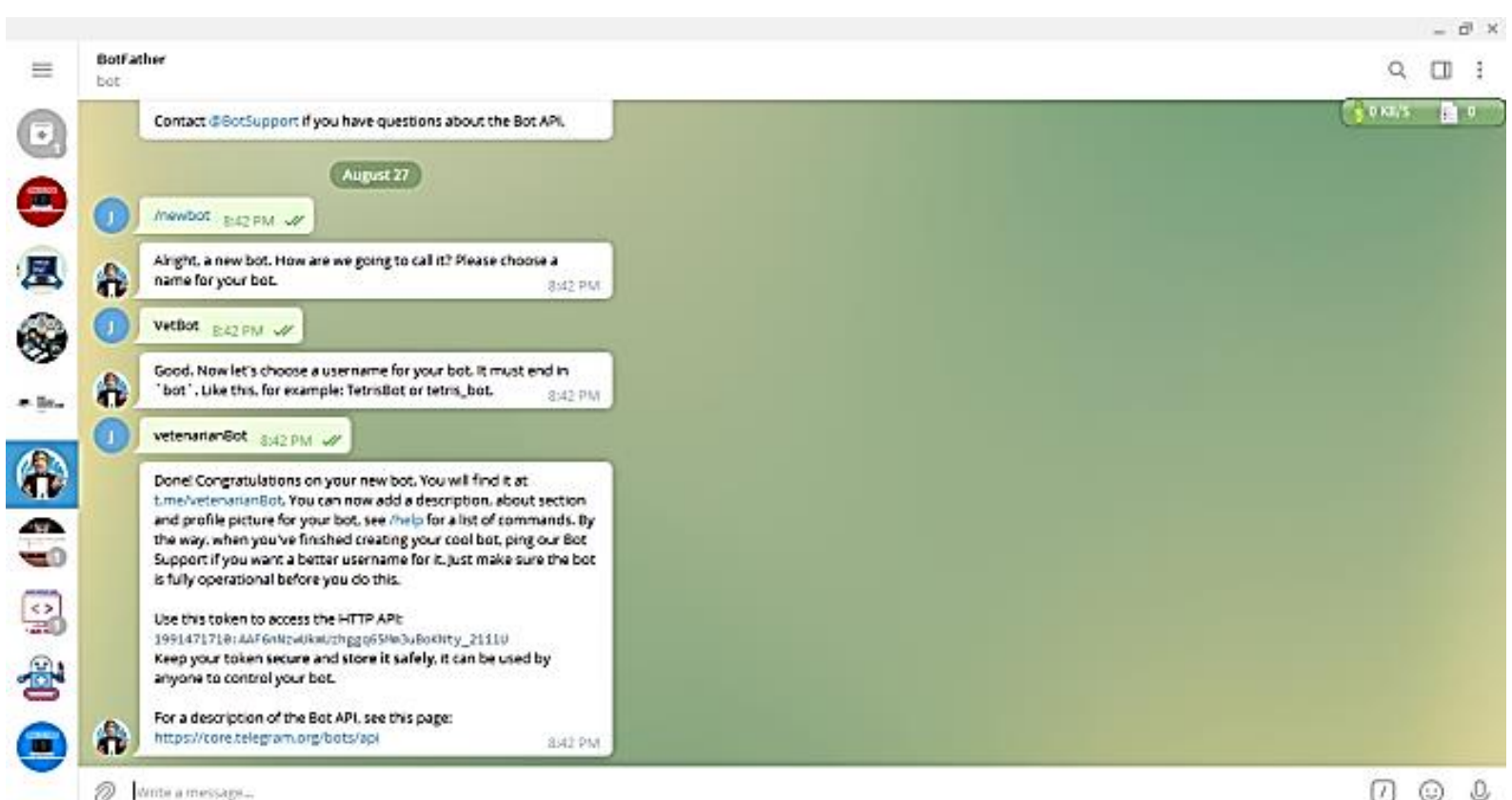

Gambar 2. Proses Registrasi Bot Baru Melalui BotFather

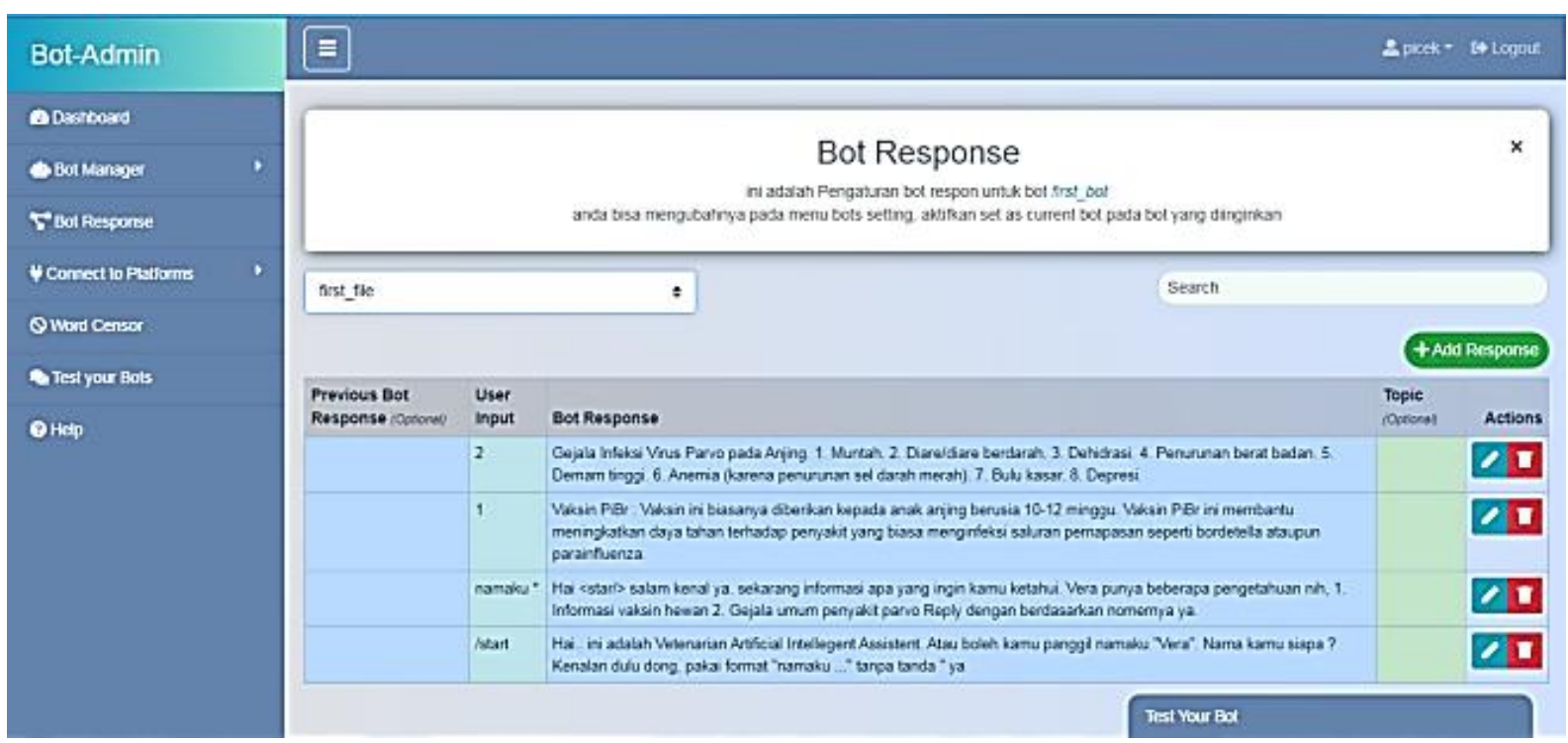

Gambar 3. Menentukan Pertanyaan serta Jawaban 


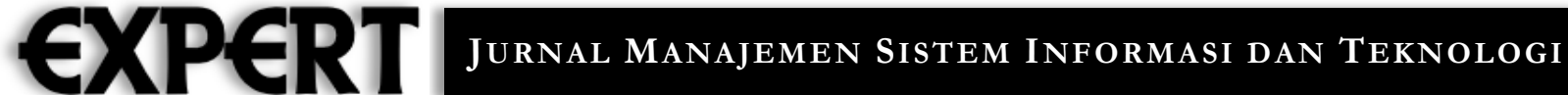

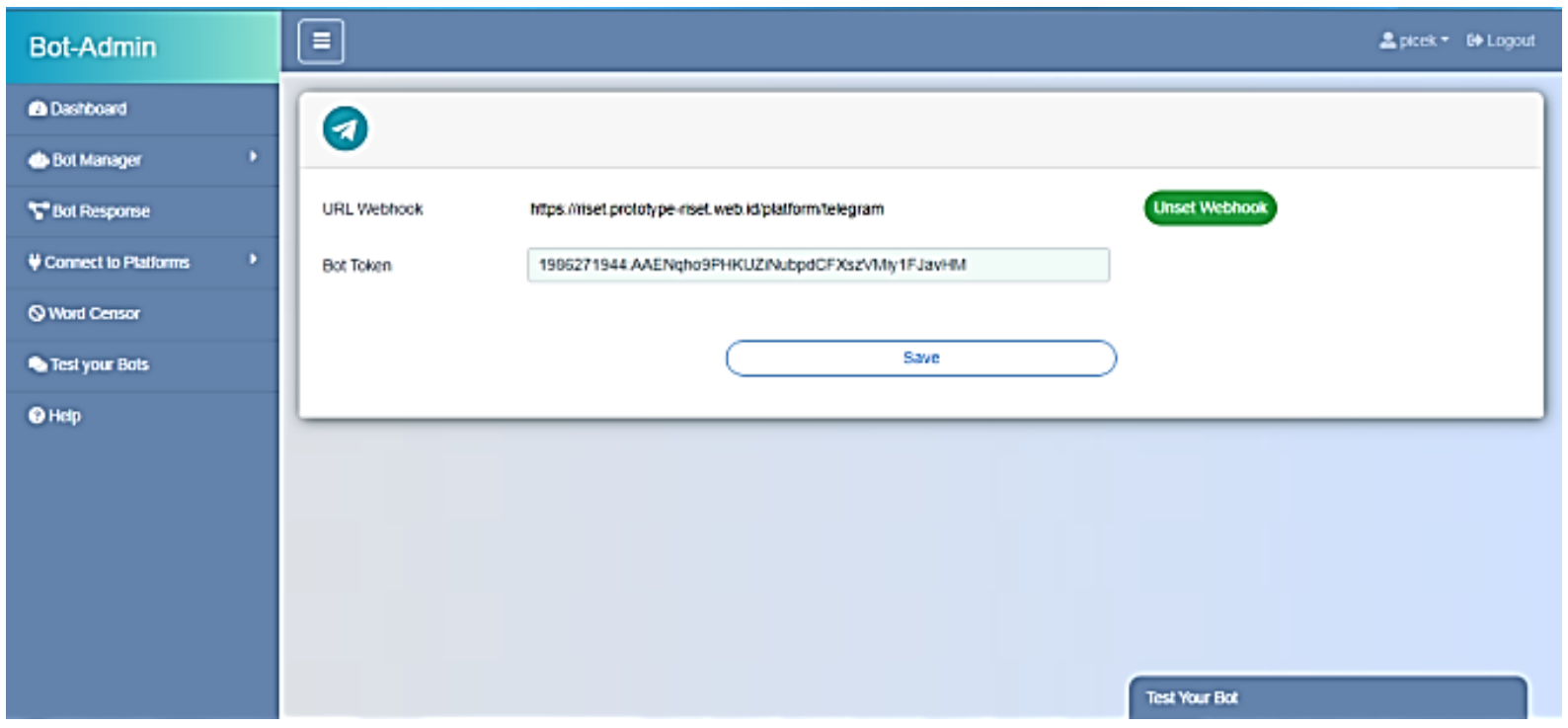

Gambar 4. Proses Integrasi Bot dengan Platform Telegram Menggunakan Metode Webhooks serta API

Tabel 1. List User Input serta Bot Response

\begin{tabular}{ccl}
\hline No & User Input & Bot Response \\
\hline 1 & /start & Hai.. ini yakni Vetenarian Artificial Intellegent Assistent. Atau boleh kamu panggil namaku \\
& "Vera". Nama kamu siapa ? Kenalan dulu dong, pakai format "namaku ..." tanpa tanda " ya \\
& Hai $<$ star/> salam kenal ya. sekarang informasi apa yang ingin kamu ketahui. \\
& Vera punya beberapa pengetahuan nih, \\
& 1) Informasi vaksin hewan \\
& 2) Gejala umum penyakit Parvo \\
& Reply dengan berdasarkan nomernya ya. \\
& Vaksin PiBr: Vaksin tersebut biasanya untuk anak anjing berumur 10-12 minggu. Vaksin \\
& PiBr ini menolong meningkatkan daya tahan pada penyakit yang biasa menginfeksi saluran \\
& pernafasan contohnya bordetella maupun parainfluenza. \\
& Gejala Infeksi Virus Parvo pada Anjing. \\
& 1) Muntah \\
& 2) Diare/Diare Berdarah \\
& 3) Dehidrasi \\
& 4) Penurunan Berat Badan \\
5) Demam Tinggi \\
6) Anemia (Karena Penurunan Sel Darah Merah) \\
7) Bulu Kasar \\
8) Depresi
\end{tabular}

Tabel 2. Pengujian Bot Melalui Aplikasi Website

\begin{tabular}{clll}
\hline No & Pengujian & Hasil yang Diharapkan & Kesimpulan \\
\hline 1. & $\begin{array}{l}\text { Mengawali interaksi dengan mengetikan } \\
\text { /start }\end{array}$ & $\begin{array}{l}\text { Bot mampu merespon dengan } \\
\text { memperkenalkan namanya (Gambar 5) }\end{array}$ & Valid \\
2 & $\begin{array}{l}\text { Memperkenalkan diri dengan mengetikan } \\
\text { Namaku di ikuti nama asli pengguna }\end{array}$ & $\begin{array}{l}\text { Bot mampu merespon dengan mengucapkan } \\
\text { salam kenal serta menampilkan pengetahuan } \\
\text { yang dimiliki (Gambar 6) }\end{array}$ & Valid \\
3 & $\begin{array}{l}\text { Menginputkan angka 1 untuk meminta Bot } \\
\text { menampilkan informasi tentang vaksin }\end{array}$ & $\begin{array}{l}\text { Bot mampu merespon dengan menampilkan } \\
\text { informasi tentang vaksin (Gambar 7) }\end{array}$ & Valid \\
4 & $\begin{array}{l}\text { Menginputkan angka 2 untuk meminta Bot } \\
\text { menampilkan informasi gejala umum } \\
\text { penyakit Parvo pada anjing }\end{array}$ & $\begin{array}{l}\text { Bot mampu merespon dengan menampilkan } \\
\text { informasi gejala umum penyakit Parvo } \\
\text { (Gambar 8) }\end{array}$ & Valid \\
\hline
\end{tabular}




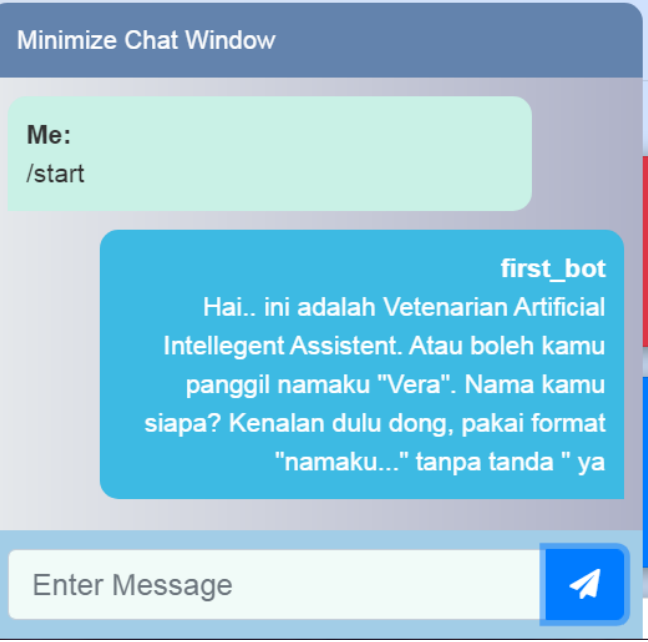

Gambar 5. Pengujian Awal Komunikasi Bot Melalui Aplikasi Berbasis Web

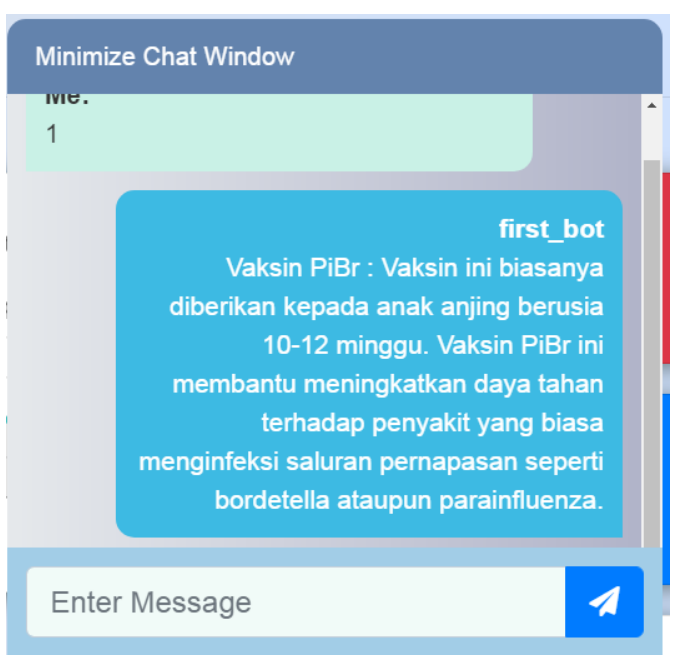

Gambar 7. Pengujian Input Knowledge Diketahui Bot Melalui Aplikasi Berbasis Web

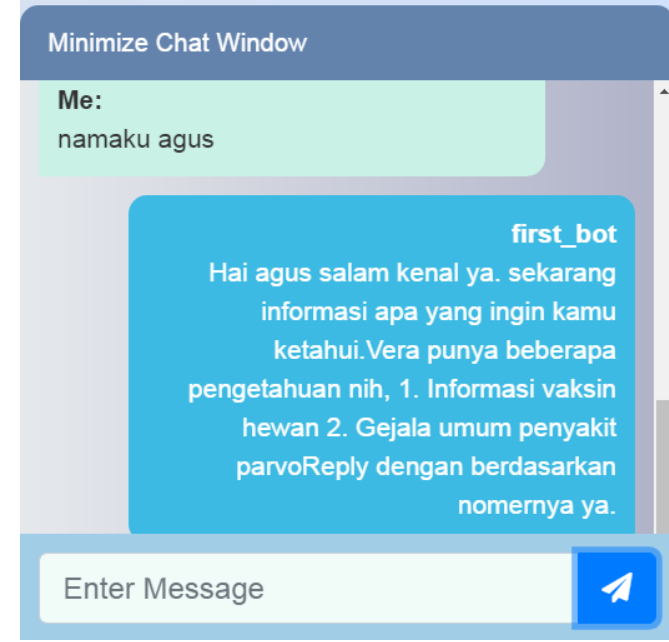

Gambar 6. Pengujian Memperkenalkan Diri Berbasis Web

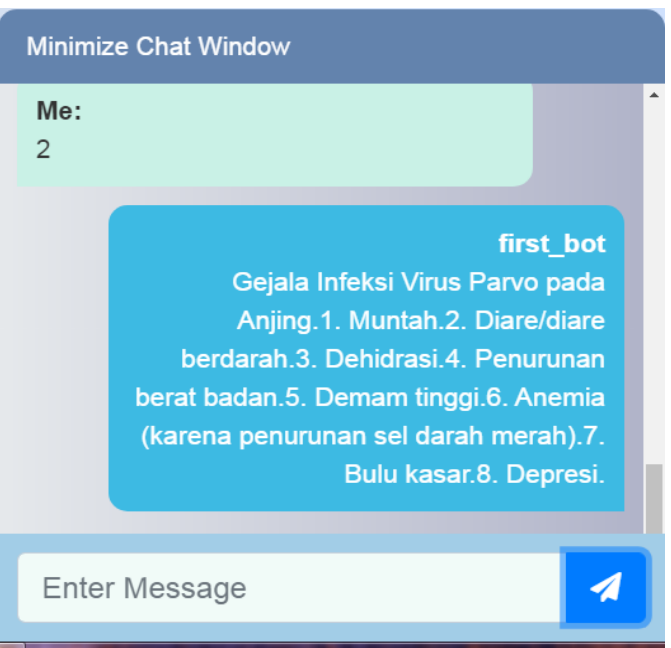

Gambar 8. Pengujian Input Knowledge

Diketahui Bot Melalui Aplikasi Berbasis Web (Lanjutan)

Tabel 3. Pengujian Komunikasi Bot Melalui Telegram

\begin{tabular}{cl}
\hline No & Pengujian \\
\hline 1 & $\begin{array}{l}\text { Mengawali interaksi dengan } \\
\text { mengetikan / start }\end{array}$ \\
2 & $\begin{array}{l}\text { Memperkenalkan diri dengan } \\
\text { mengetikan Namaku di ikuti nama asli } \\
\text { pengguna }\end{array}$
\end{tabular}

Hasil yang di harapkan

Bot mampu merespon dengan memperkenalkan

namanya sama seperti pada aplikasi website

(Gambar 9)

Bot mampu merespon dengan mengucapkan

salam kenal serta menampilkan pengetahuan yang

dimiliki. sama seperti pada aplikasi website

(Gambar 10)

3 Menginputkan angka 1 untuk meminta Bot menampilkan informasi tentang vaksin

4 Menginputkan angka 2 untuk meminta Bot menampilkan informasi gejala umum penyakit Parvo pada anjing
Bot mampu merespon dengan menampilkan informasi tentang vaksin. sama seperti pada aplikasi website (Gambar 11)

Bot mampu merespon dengan menampilkan informasi gejala umum penyakit Parvo. sama seperti pada aplikasi website (Gambar 12)
Valid

Kesimpulan Valid

Valid

Valid 


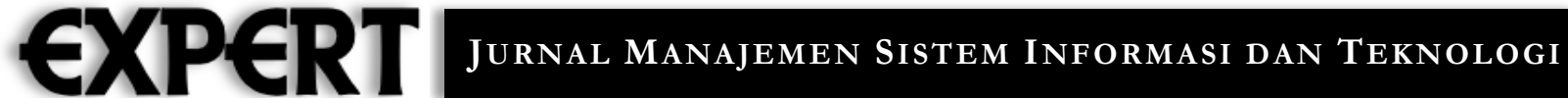

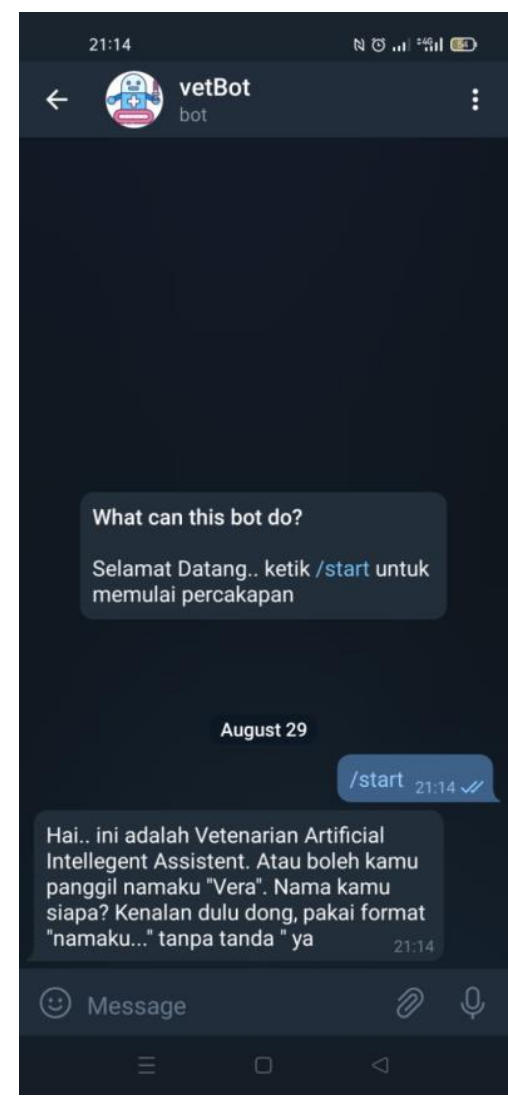

Gambar 9. Pengujian Komunikasi Bot Melalui Telegram

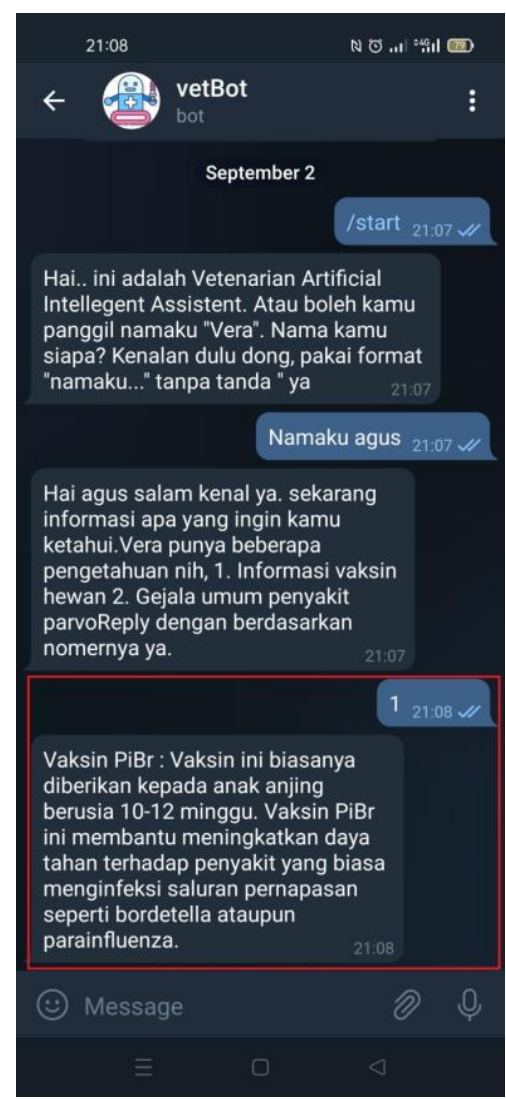

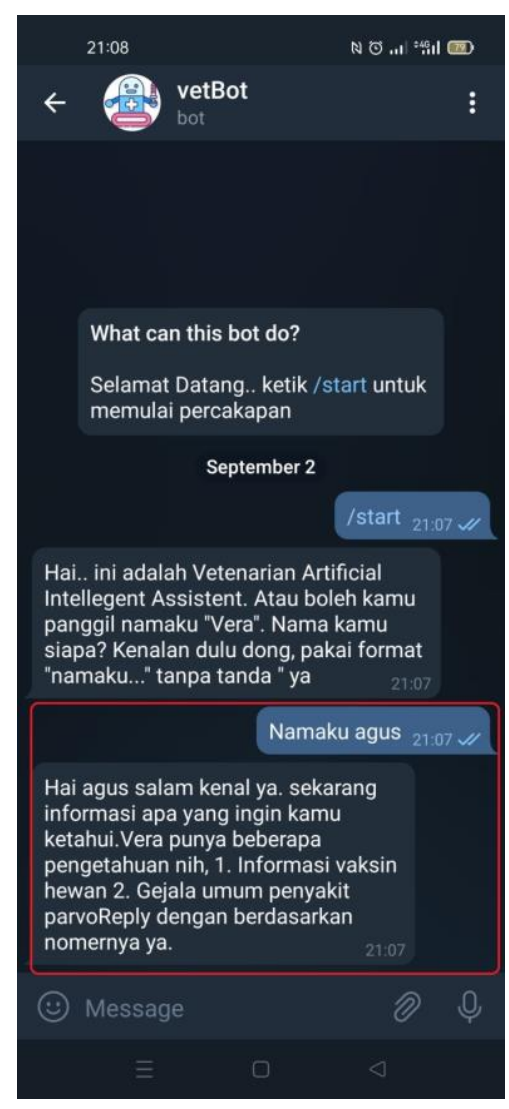

Gambar 10. Pengujian Komunikasi Bot Memperkenalkan Diri Melalui Telegram

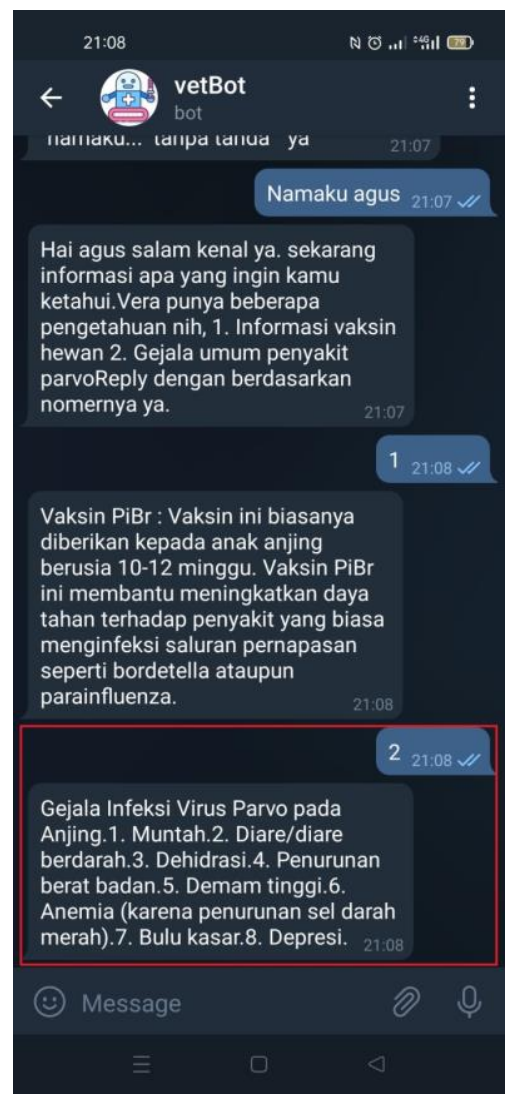

Gambar 11., Gambar 12. Pengujian Knowledge Sharing Bot Melalui Telegram 


\section{Kesimpulan}

Sesuai pemaparan serta perolehan pengujian system bisa disimpulkan bahwasanya penelitian ini sudah dapat berkomunikasi atau membagikan pengetahuannya sesuai dengan yang sudah di inputkan sebelumnya melalui platform Telegram. serta aplikasi ini dapat membagian pengetahuan tentang Parvo virus yang menyerang anjing sehingga para pemilik anjing dapat mengidentifikasi lebih awal gejala Parvo virus. Untuk saat ini pengetahuan yang dimiliki oleh aplikasi ini masih sangat minim sehingga saran yang bisa diberi dalam kepenelitian yakni memperkaya pengetahuan yang dimiliki oleh aplikasi chatBot tersebut akhirnya bisa memberi berita sangat runtut serta tepat guna tentang penyakit Parvo.

\section{Daftar Pustaka}

[1] N. Decaro, C. Buonavoglia, And V. R. Barrs, "Canine Parvovirus Vaccination And Immunisation Failures: Are We Far From Disease Eradication?," Vet. Microbiol., Vol. 247, P. 108760, Aug. 2020, DOI: 10.1016/j.vetmic.2020.108760.

[2] S. Giraldo-Ramirez, S. Rendon-Marin, And J. Ruiz-Saenz, "Phylogenetic, Evolutionary And Structural Analysis Of Canine Parvovirus (Cpv-2) Antigenic Variants Circulating In Colombia," Viruses 2020, Vol. 12, Page 500, Vol. 12, No. 5, P. 500, Apr. 2020, DOI: 10.3390/v12050500.

[3] A. Subagio, "Prospek Pemanfaatan Imunoglobulin Y Untuk Terapi Infeksi Canine Parvovirus Pada Anjing," DOI: 10.14334/wartazoa.v25i2.1142.

[4] I. K. W. Adnyana and Y. H. Wirawan, "Perancangan Arsitektur Knowledge Management System (KMS) pada Lembaga LPPM (Studi Kasus : LPPM STMIK STIKOM Indonesia)," Maj. Ilm. Unikom, Vol. 17, No. 2, Pp. 103-110, Feb. 2020, DOI: $10.34010 /$ miu.v17i2.3185.

[5] R. S. Andra And H. N. Utami, "Pengaruh Knowledge Sharing Terhadap Kinerja Karyawan (Studi pada Karyawan P'T Bank Rakyat Indonesia Kantor Cabang Malang Kawi)," J. Adm. Bisnis, Vol. 61, No. 2, Pp. 30-37, 2018, Accessed: Jan. 29, 2021. [Online]. Available: http://administrasibisnis.studentjournal.ub.ac.id/i ndex.php/jab/article/view/2569.
[6] S. S. Abhishek Singh, Karthik Ramasubramanian, "Building An Enterprise ChatBot. Work With Protected Enterprise Data Using ... - Abhishek Singh, Karthik Ramasubramanian, Shrey Shivam Google Books."

https://books.google.co.id/books?hl=en\&lr=\&id $=$ ixuvdwaaqbaj\&oi $=$ fnd $\& p g=$ pr $5 \& \mathrm{dq}=$ chatbot + bo ok\&ots $=$ ylp-zcljsw \&sig $=$ vqz 85 en $2 \mathrm{wm}-$

19uglpnuarrlzui\&redir_esc $=\mathrm{y} \# \mathrm{v}=$ onepage $\& \mathrm{q}=$ chatb ot book\&f $=$ false (Accessed Dec. 08, 2021).

[7] M. Sarosa, A. Suyono, M. K. \#3, And Z. Sari, "Jepin (Jurnal Edukasi dan Penelitian Informatika) Implementasi ChatBot Pembelajaran Bahasa Inggris Menggunakan Media Sosial," Jepin (Jurnal Edukasi Dan Penelit. Inform., Vol. 6, No. 3, Pp. 317-322, Dec. 2020, Accessed: Dec. 27, 2020. [Online]. Available:

https://jurnal.untan.ac.id/index.php/jepin/article /view/43191.

[8] L. Athota, V. K. Shukla, N. Pandey, and A. Rana, "ChatBot For Healthcare System Using Artificial Intelligence," In Icrito 2020 - Ieee 8th International Conference On Reliability, Infocom Technologies And Optimization (Trends And Future Directions), Jun. 2020, Pp. 619-622, DOI: 10.1109/icrito48877.2020.9197833.

[9] W. Febriantoro and A. Nurhadi, "Perancangan Intelligent Tutoring System Menggunakan ChatBot pada Mata Pelatihan Barang dalam Keadaan Terbungkus," Pancanaka J. Kependudukan, Keluarga, Dan Sumber Daya Mns., Vol. 1, No. 1, Pp. 10-20, Jan. 2020, DOI: 10.37269/pancanaka.v1i1.33.

[10] J. Zhang, Y. J. Oh, P. Lange, Z. Yu, and Y. Fukuoka, "Artificial Intelligence ChatBot Behavior Change Model for Designing Artificial Intelligence ChatBots to Promote Physical Activity and A Healthy Diet: Viewpoint," Journal Of Medical Internet Research, Vol. 22, No. 9. Jmir Publications, Sep. 30, 2020, DOI: $10.2196 / 22845$.

[11] H. Derajad Wijaya, W. Gunawan, R. Avrizal, and S. M. Arif, "IJISCS | 8 Designing ChatBot for College Information Management." 